\title{
LENGTH AND WEIGHT RELATIONSHIP AND GROWTH PERFORMANCE OF Meretrix casta UNDER EXPERIMENTAL CULTURE CONDITION IN THREE DIFFERENT ESTUARINE ENVIRONMENT
}

\author{
G.Srilatha*, T.Manikandarajan, K.Ramamoorthy, K.Sundaravarman, \\ G.Sankar, R.Anbarasu
}

\author{
Centre of Advanced Study in Marine Biology, Faculty of Marine Sciences, \\ Annamalai University, Parangipettai - 608 502, Tamil Nadu, India. \\ E-mail address: thillairaja01@gmail.com
}

Keywords: Length, Weight, Growth performance, Meretrix casta.

\begin{abstract}
The Meretrix casta is an edible clam for human beings and it is widely distributed around the aquatic ecosystem. The clam has relatively thick shells that can attain a length of three inches. The knowledge of the biology, culture and biochemical composition of any edible organism is extremely important. Though the size, shape and colour of clam are different their nutritive value is very good. A maximum average length of $27.15 \mathrm{~mm}$ was observed in the M.casta studied during 2011 and a maximum average length of $26.51 \mathrm{~mm}$ was observed during 2012 . The average lengths of M.casta in all the three different estuaries studied were as follows: $27.15>25.82>25.04 \mathrm{~mm}$ in 2011 and $26.51>25.88>25.17 \mathrm{~mm}$ in 2012 . A maximum average weight of 7.824 and $7.155 \mathrm{~g}$ was observed during 2011 and in 2012; a maximum weight of $7.528 \mathrm{~g}$ and minimum of $6.941 \mathrm{~g}$ was recorded uniformly in all the three different estuaries. However, in 2011 and 2012 a maximum and minimum of average length of $26.86,25.10 \mathrm{~mm}$, and average weight of 7.67 and $7.05 \mathrm{~g}$ respectively were noticed in both Vellar and Uppanar estuaries of M.casta. the present investigation, it is clearly observed that M.casta can grow a weight of $0.13 \mathrm{~g}$ /day and length of $0.122 \mathrm{~mm} /$ day among the three different estuaries studied in the Cuddalore district which is located in Bay of Bengal.
\end{abstract}

\section{INTRODUCTION}

The seafood is a real health food and brain food too for humans. It is also organic in nature. It is easily digestible because it has very little connective tissue. For the above reason, fin fishes and shell fishes are recommended as special diets around the world. A newer species should be recommended for human consumption only after assessing the biology of the species with regard to its nutritional merits.

The Meretrix casta is an edible clam for human beings and it is widely distributed around the aquatic ecosystem. The clam has relatively thick shells that can attain a length of three inches. The knowledge of the biology, culture and biochemical composition of any edible organism is extremely important. Though the size, shape and colour of clam are different their nutritive value is very good. The clam aquaculture is significant and most valuable of the shellfish for aquaculture industry, [1, 2, and 3]. The past two decades have seen a rapid expansion of alternative and innovative methods for the cultivation of clams. However, there is little information on the effects of these practices on the surrounding environment, [4].

The environmental parameters can affect the bivalve population densities and growth of clams. These basic aspects have been studied previously by several researchers, [5, 6, 7, and 9]. The clam meats are having high demand in locally and globally indicating the importance for culture. Increasing clam production to meat of clam and subsequent enhancing captive culture is only way to meet the demand. Aim of the present study is to evaluate the length and weight relationship and growth performance of M.casta in three different (Vellar, Uppanar and Pennaiyar) estuarine environment. 


\section{MATERIALS AND METHODS}

The seeds of M.casta were collected from the natural clam beds in different sampling sites (brackish water) Vellar, Uppanar and Pennaiyar estuaries along Tamilnadu coast. The seeds were collected (Plate $1 \mathrm{a}-\mathrm{d}$ ) with an average total length of $20 \mathrm{~mm}$ and average total weight of $1.50 \mathrm{~g}$ in each estuary (Plate 1c-d).

The experimental trials were made for ten month between each month internal from January - October 2011 and January - October 2012. In each sampling site more than thirty individuals of M.casta seeds were collected by manual picking and placed in a plastic basket. Upon collection the seeds from each estuary, the clam seeds were stocked in pre-fabricated nylon cages of $1 \mathrm{~mm}$ mesh size $(100 \times 50 \times 5 \mathrm{~cm})$. The bottom set cages were stocked evenly in each estuary with 30 numbers / $\mathrm{m} 2$. The growth and survival were studied at monthly interval by studying total length and weight of the estuarine clam M.casta.

\section{RESULTS}

A maximum average length of $27.15 \mathrm{~mm}$ was observed in the M.casta studied during 2011 and a maximum average length of $26.51 \mathrm{~mm}$ was observed during 2012 . The average lengths of M.casta in all the three different estuaries studied were as follows: $27.15>25.82>25.04 \mathrm{~mm}$ in 2011 and $26.51>25.88>25.17 \mathrm{~mm}$ in 2012 . No significant differences were noticed in the average length of M.casta during 2011 and 2012 respectively.

A maximum average weight of 7.824 and $7.155 \mathrm{~g}$ was observed during 2011 and in 2012; a maximum weight of $7.528 \mathrm{~g}$ and minimum of $6.941 \mathrm{~g}$ was recorded uniformly in all the three different estuaries. However, in 2011 and 2012 a maximum and minimum of average length of 26.86, $25.10 \mathrm{~mm}$, and average weight of 7.67 and $7.05 \mathrm{~g}$ respectively were noticed in both Vellar and Uppanar estuaries of M.casta. Although in 2011, a highest average length of $37.70 \mathrm{~mm}$ and a least average length of $6.8 \mathrm{~mm}$ were recorded in both Vellar and Uppananr estuaries.

\section{Plate - 1}

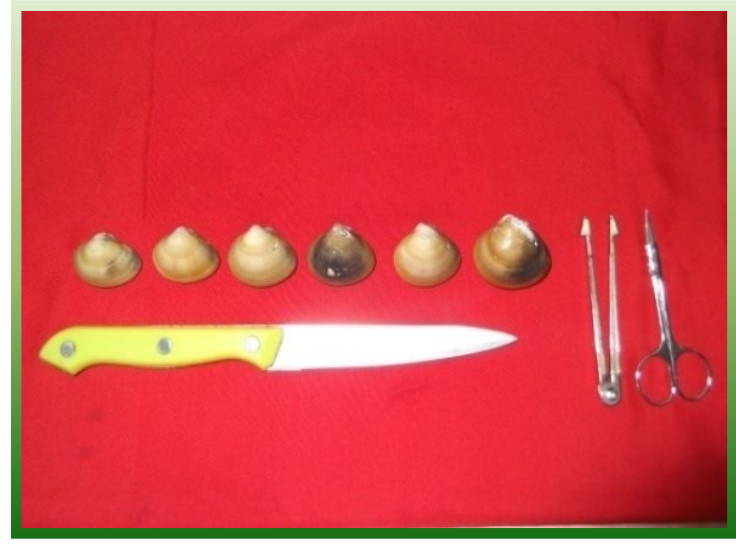

a) View of M.casta prior evaluation

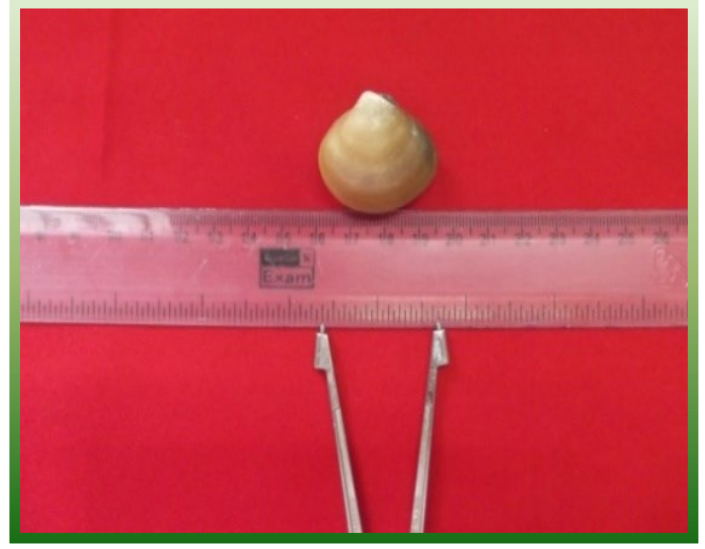

b) View of M.casta whilst evaluation 


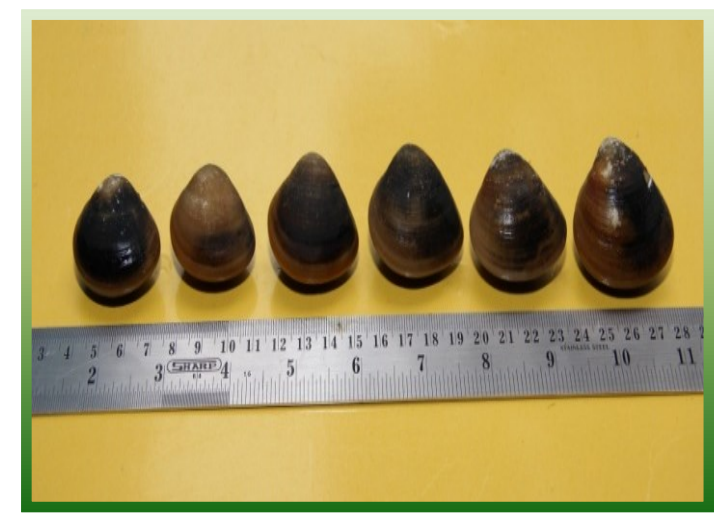

c) Enlarged view of M.casta during length \& weight assessment

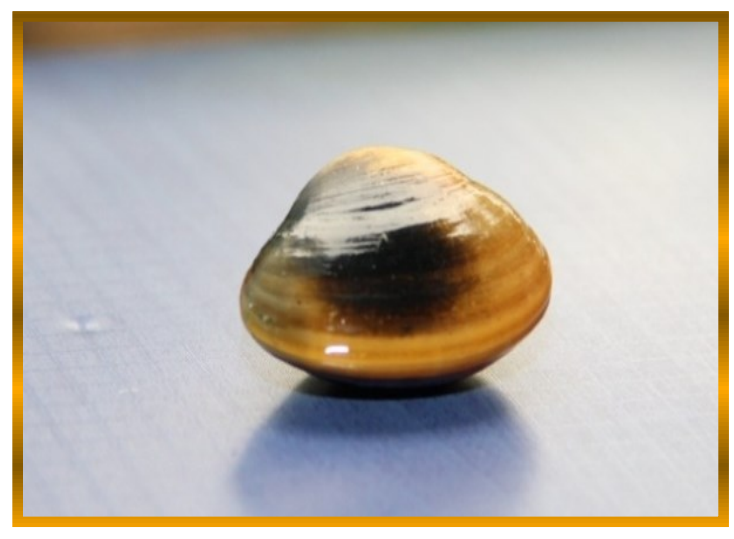

d) View of an individual M.casta

Table.1 Initial and final length and weight of M.casta during 2011 in three different estuaries

\begin{tabular}{|c|c|c|c|c|}
\hline \multirow{2}{*}{ Estuaries } & \multicolumn{2}{|l|}{ Minimum } & \multicolumn{2}{|l|}{ Maximum } \\
\hline & Length (mm) & Weight (g) & Length (mm) & Weight (g) \\
\hline Vellar & 7.8 & 1.07 & 37.7 & 12.8 \\
\hline Uppanar & 6.8 & 1.02 & 34.6 & 11.5 \\
\hline Pennaiyar & 7.1 & 1.03 & 35.8 & 12.2 \\
\hline
\end{tabular}

Table.2 Initial and final length and weight of M.casta during 2012 in three different estuaries

\begin{tabular}{|c|c|c|c|c|}
\hline \multirow{2}{*}{ Estuaries } & \multicolumn{2}{|l|}{ Minimum } & \multicolumn{2}{|l|}{ Maximum } \\
\hline & Length (mm) & Weight (g) & Length (mm) & Weight (g) \\
\hline Vellar & 7.5 & 1.04 & 39.5 & 12.3 \\
\hline Uppanar & 6.7 & 0.94 & 35.3 & 11.2 \\
\hline Pennaiyar & 7.2 & 0.99 & 36.4 & 11.9 \\
\hline
\end{tabular}

On the other hand, in 2012 the average length and weight parameters were recorded as $37.5 \mathrm{~mm}$ and $6.7 \mathrm{~g}$ in both Vellar and Uppanar estuaries respectively. In 2011 and 2012, a highest average weight of $12.8,12.3 \mathrm{~g}$ and a least average weight of 1.02, $0.94 \mathrm{~g}$ were recorded with the clam M.casta studied in Vellar and Uppanar estuaries.

The weight ranged from 0.94 and $13.42 \mathrm{~mm}$. The maximum length of $13.42 \mathrm{~mm}$ was recorded in the Vellar estuary during October 2011 and a minimum of $0.94 \mathrm{~mm}$ was recorded in the Uppanar estuary in the month of January 2012. 


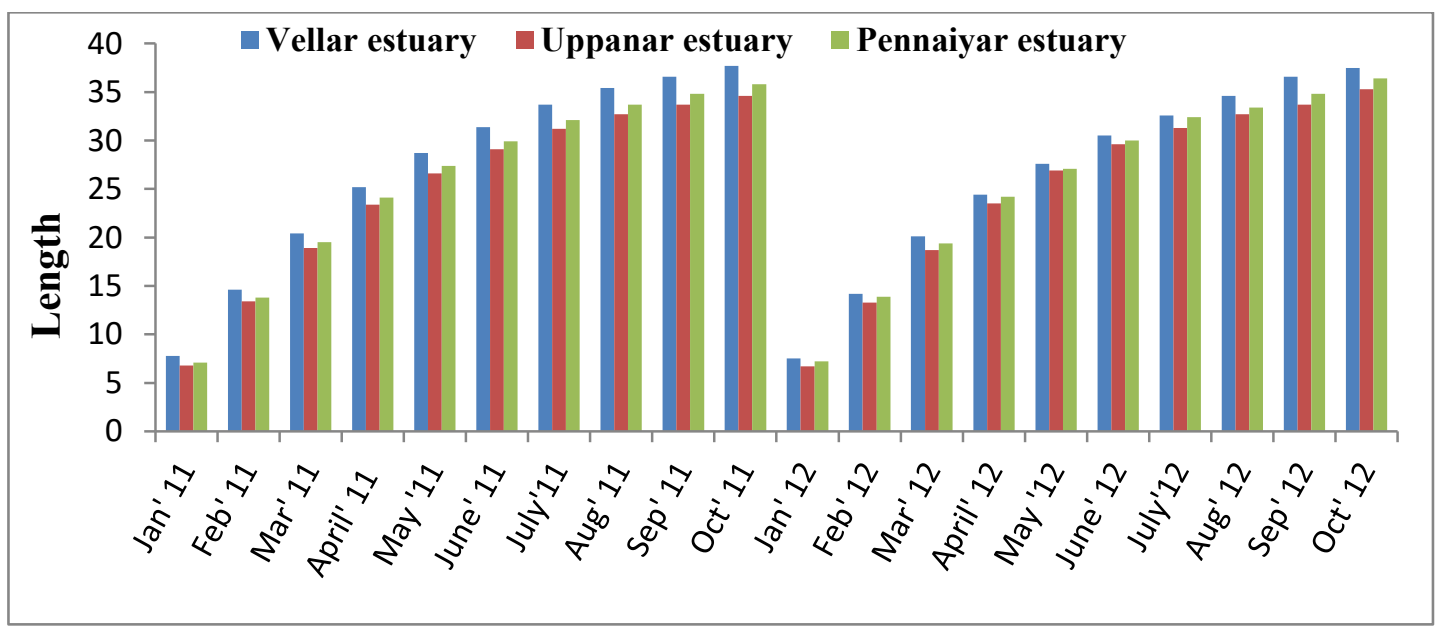

Fig., 1.Variation in the Length of M.casta of three different estuaries during 2011 \& 2012

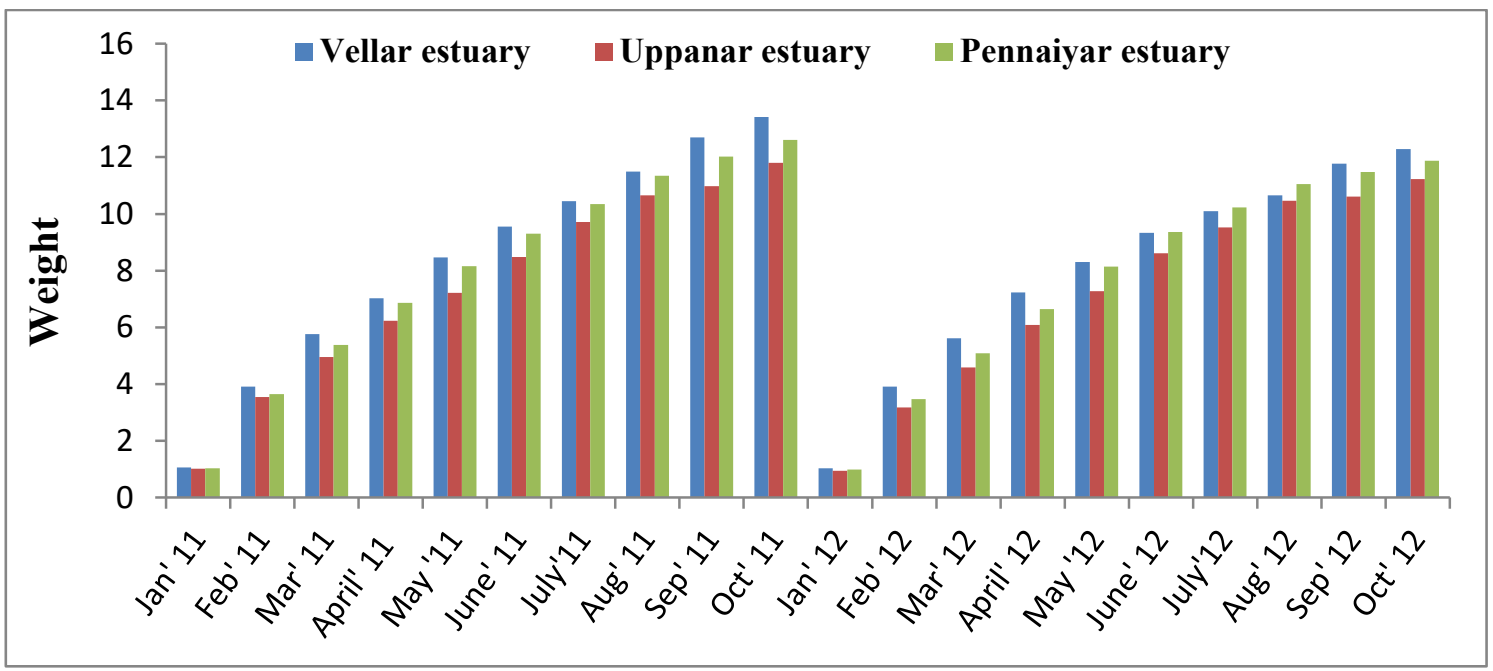

Fig., 2.Variation in the weight of M.casta in three different estuaries during $2011 \& 2012$

In Vellar estuary, the length of the clam varied from 7.5 and $37.7 \mathrm{~mm}$. The maximum length recorded was in $37.7 \mathrm{~mm}$ in the month October 2011 and the minimum recorded as $7.5 \mathrm{~mm}$ in the month January 2012 (Fig., 3\&Table.1) and during this period the weight of M.casta varied from 1.04 to $13.42 \mathrm{~g}$. The maximum weight of $13.42 \mathrm{~g}$ was recorded in October 2011 and a minimum of $1.04 \mathrm{~g}$ was recorded during January 2012.

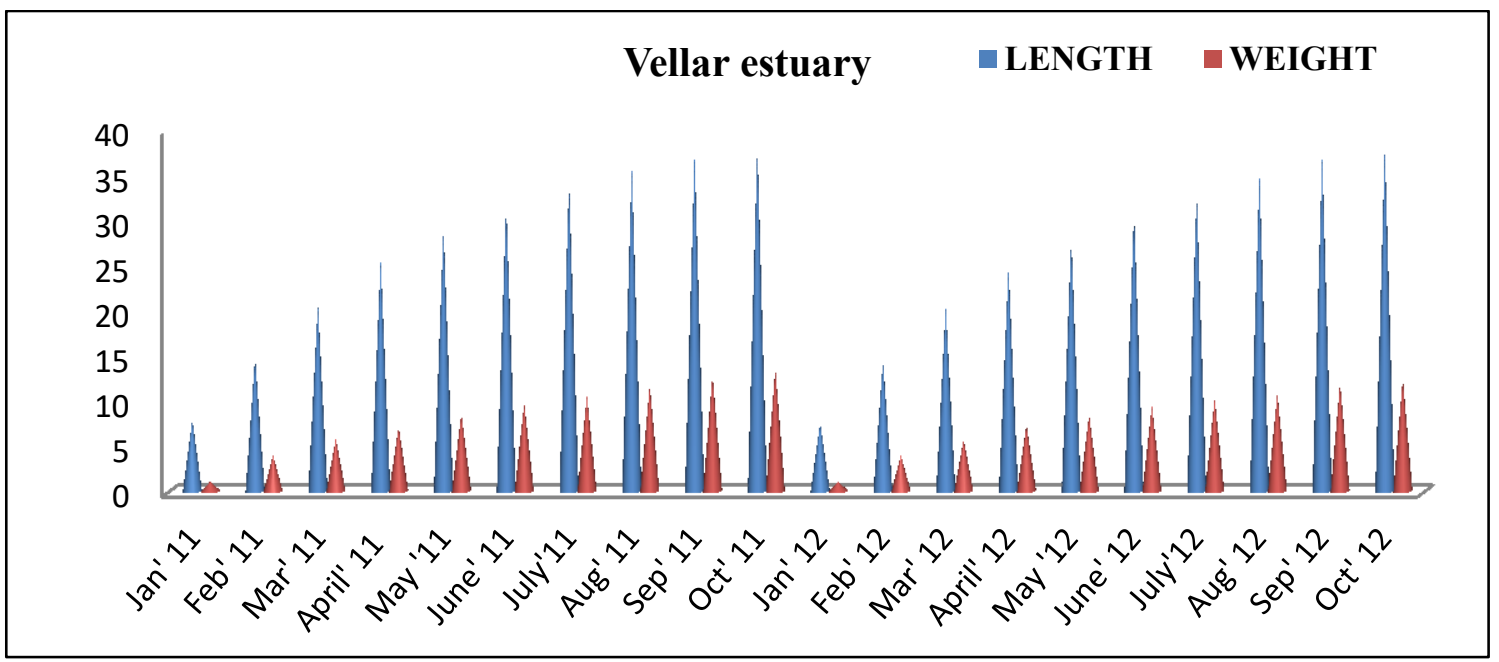

Fig., 3. Variation in the length and weight of M.casta of Vellar estuary during 2011 \& 2012 
In Vellar estuary, the length of M.casta varied from 7.5 and $37.7 \mathrm{~mm}$. The maximum length of $37.7 \mathrm{~mm}$ was recorded in October 2011 and a minimum of $7.5 \mathrm{~mm}$ was recorded in January 2012 . The weight of clam varied from 1.04 and $12.84 \mathrm{~g}$. A maximum weight of $12.84 \mathrm{~g}$ was recorded October 2011 and a minimum of 1.04g was recorded in January 2012.

In Uppanar estuary, the length of M.casta varied from 6.7 and $35.3 \mathrm{~mm}$. A maximum length of $35.3 \mathrm{~mm}$ was recorded in October 2011 and a minimum of $6.7 \mathrm{~mm}$ was recorded in January 2012. The weights of M.casta were varied from 0.94 and 11.8g (Fig., 4 \& Table 2). A maximum weight of $13.42 \mathrm{~g}$ was recorded in October 2011 and a minimum of $0.94 \mathrm{~g}$ was recorded in January 2012.

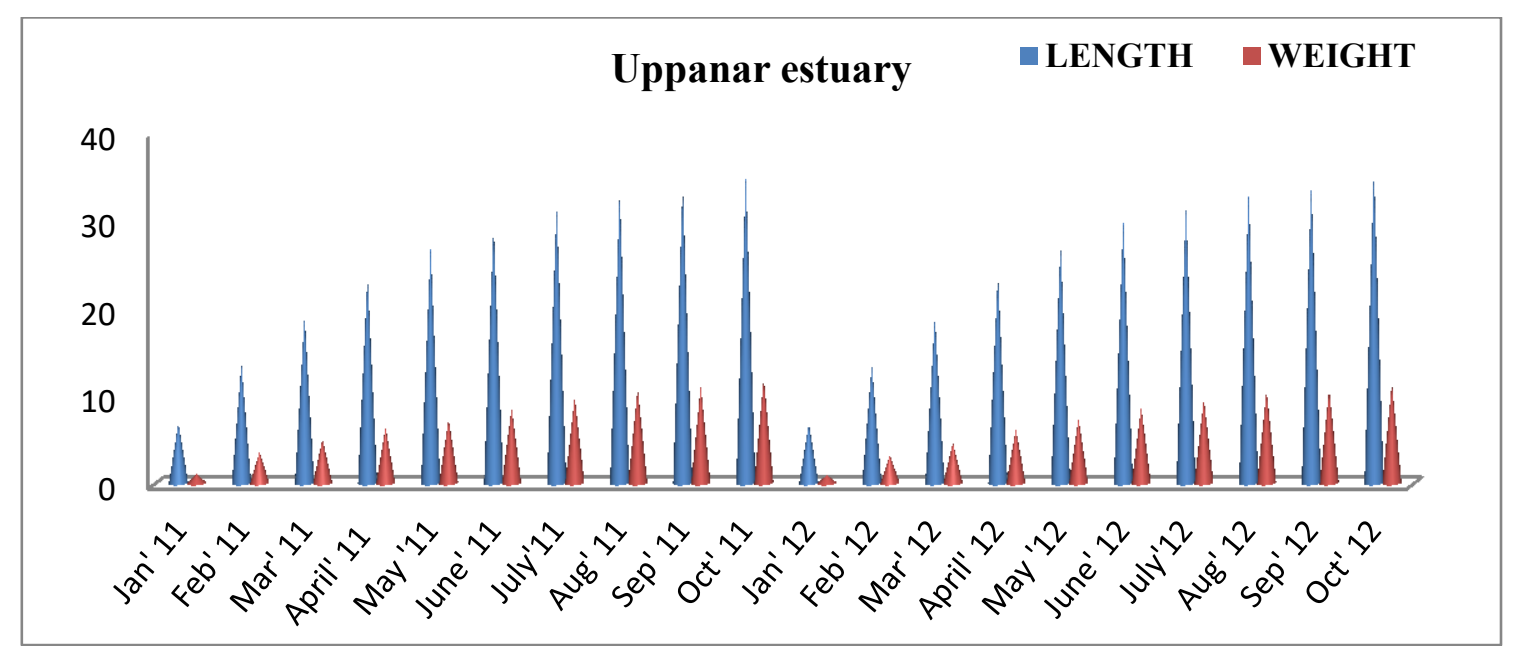

Fig., 4.Variation in the length and weight of M.casta of Uppanar estuary during 2011 \& 2012

In Penniyar estuary, the length of M.casta varied from 7.1 and $36.4 \mathrm{~mm}$. A maximum length of $36.4 \mathrm{~mm}$ was recorded in October 2012 and a minimum of $7.1 \mathrm{~mm}$ was recorded in January 2011. The weight of M.casta varied from 0.99 and $12.6 \mathrm{~g}$ and a maximum weight of $12.6 \mathrm{~cm}$ was recorded in October 2011 and a minimum of 1.04g was recorded in January 2012 (Fig., 4 ).

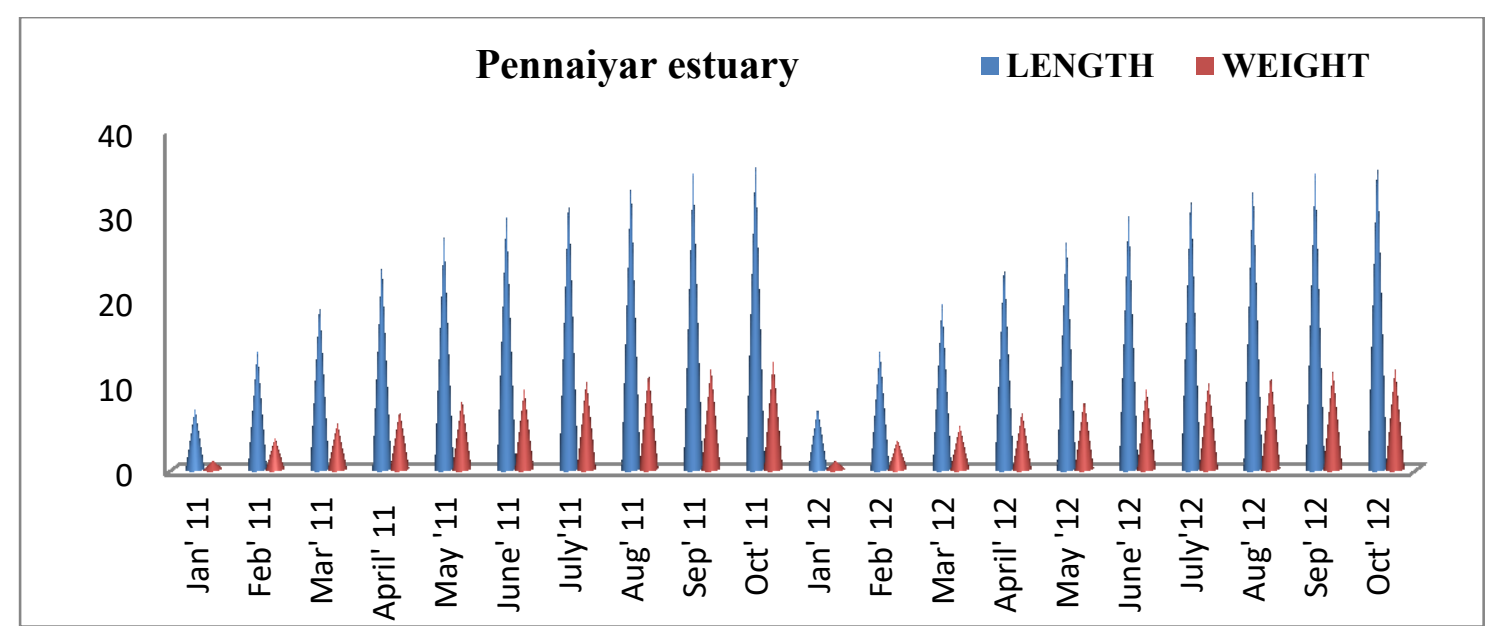

Fig. 5. Variation in the length and weight of M.casta of Penniyar estuary during $2011 \& 2012$

\section{DISCUSSION}

The yellow clam Meretrix casta forms a significant sustenance - level fishery in all major estuaries of India, [9]. The M. casta is euryhaline and hence can tolerate wide range of salinities and prefers high sand and silt habitat, [10]. The collections of edible clams were dependent on the spat fall and subsequent recruitment of the fishery. Salinity, temperature sediment texture and organic matter contribute to the abundance of bivalves, [11].

The abundance of $M$. casta is positively correlated to the organic matter content in the substrate, [12, and 13]. The salinity and total suspended solids (TSS) were critical factors influencing the abundance of estuarine clams. The $\mathrm{pH}$ and iron concentrations in bottom sediment 
water strongly related to clam densities, $[13,14]$. The monthly average growths of $\mathrm{M}$. casta were slightly higher in Vellar estuary than Uppanar and Penniyar estuaries. The monthly average growth of $7.5 \mathrm{~mm}$ was recorded in the Vellar estuary and it was $6.7 \mathrm{~mm}$ in Uppanar estuary whereas in Penniyar estuary the growth of the clam noticed $7.1 \mathrm{~mm}$ respectively. The yellow clam $M$. casta attained a maximum of $37.7 \mathrm{~mm}$ in Vellar estuary, $35.3 \mathrm{~mm}$ in Uppanar estuary and $36.4 \mathrm{~mm}$ in Penniyar estuary in 10 months. However, M. casta was reported to have attained $33.5 \mathrm{~mm}$ in the period of 9 months as reported by [15].35.4 mm length in 11 months in Cochin Barmouth estuary, West coast as accounted by [15]. However, [16] was reported slower growth of $0.79 \mathrm{~mm}$ per month was reported in Mandapam and this was due to high salinity in the Gulf of Mannar region. [17] reported the growth of $34 \mathrm{~mm}$ in 13 month in $M$. casta transplanted to Vellar estuary. [18] Reported $23,38.30$ and $50.6 \mathrm{~mm}$ growth in the subsequent 1,2 and $3^{\text {rd }}$ year of study period in the yellow clam $M$. casta in the Vellar estuary.

These variations in growth are due to the changes in the hydrological conditions in the estuaries as mentioned by [18, 19, and 17]. The weight of clam of Vellar estuary ranged from 1.04 to $13.42 \mathrm{~g}$ and in Uppanar estuary ranged from 0.94 to $11.8 \mathrm{~g}$ subsequently in the Penniyar estuary range varied from 0.99 to $12.6 \mathrm{~g}$. The weight of clam M.casta found higher in Vellar estuary $(13.42 \mathrm{~g})$ than in other estuaries namely Uppanar and Penniyar etc., The hydrographical conditions and productivity of the three estuaries have an important bearing on the growth of the clams as pointed out by $[1,20]$. The condition indexes of the clams from study area were almost same. Nevertheless, the clam M. casta studied in Adyar backwater has been reported to attain a size of over $56.5 \mathrm{~mm}$ in a period of three years. Although, in the Adyar backwater more than 95\% of the clams are fished before they reach a length of $30 \mathrm{~mm}$ [1]. In Korapuzha and Beypore estuaries of West coast, the maximum size of $31 \mathrm{~mm}$ was obtained during 1950-1951 [20]. In Bhimunipatnam estuary on the East coast also the same values were recorded. The $M$. casta of over $20 \mathrm{~mm}$ formed only $5 \%$ of the fished clams and there over $40 \mathrm{~mm}$ were rare, [21]. Similarly in Chaliyar and Kavvai estuaries, clams of over $40 \mathrm{~mm}$ were rarely seen. The growth parameters reported for M.casta from five different sites in the Dutch canal of Sri Lanka ranges from 34 to $43.1 \mathrm{~mm}$, [22]. The ranges of growth were $M$. casta from all study areas are nearly the same and growth was isometric. Isometric growth has been reported in M. casta, [23]. The factors that have enabled this resilience are the high rate of growth, especially during early stages $1-3$ month (growth rate $6.7 \mathrm{~mm}$ ), the abbreviated larval stages, early attainment of sexual maturity, discontinuous breeding throughout the year with at least two peaks and euryhaline tolerance to salinity, [18, 13and 24]. The growth rate of M. casta were estimated in Vellar estuary was higher than that of Uppanar and Penniyar estuaries. Heavy mortality due to heavy flooding in the West coast and poor yield of clam in the Mumbai coast due to excessive rainfall have been reported by $[25,26]$.

However, the major issue of concern is the changes in the habitat or sand bed of the clams. Large scale sand mining also affects the spat settlement due to high levels of total suspended solids, [27]. The yellow clam M. casta is intensely fished from the most estuaries for the meat (for local consumption) and maturation feed for shrimp brood stock development besides as feed in aquaculture practicing ponds. The undersized clams are exploited during the peak season, the meat is allowed to putrefy and shells are used by the lime industry, [26].This affects the livelihood of the fishers, dependent on this important fishery for their sustenance.

It is well known that in bivalves the rate of growth is rapid during early part of life and the growth decreases as the clams advance in age. [1]. Observed faster growth in the early part of the life of $M$. casta and the specimens attained $20.4 \mathrm{~mm}$ within two months and $36.6 \mathrm{~mm}$ within ten months. During the course of the present study, it was observed that the young clams grew to a size of $36.6 \mathrm{~mm}$ in 10 months, showing a growth rate of $3.8 \mathrm{~g} /$ month. The salinity was found to influence the growth of marine bivalves at Madras. The factors such as salinity, dissolved oxygen, phosphates, organic contents, silt and nature of the bottom are believed to affect the health and condition of shell-fish, [28, 29 and 30] have reported the age and growth of M. casta and observed a mean growth of $17 \mathrm{~mm}$ in six months and the growth at the end of one year was found to be about $24 \mathrm{~mm}$. [31] observed the size of $M$. casta to be larger, which ranged between 44 and $55 \mathrm{~mm}$ with a 
mean size of $49.44 \mathrm{~mm}$. Obviously, from the present investigation, it is clearly observed that M.casta can grow a weight of $0.13 \mathrm{~g} /$ day and length of $0.122 \mathrm{~mm} /$ day among the three different estuaries studied in the Cuddalore district which is located in Bay of Bengal.

\section{ACKNOWLEDGEMENT}

The Authors would like to my Research Supervisor Dr.K.Ramamoorthy, M.Sc., Ph.D., Dr.G.Sankar, M.Sc., Ph.D., and for help and encouragement, the UGC - New Delhi, India for financial support, internet facility and Laboratory facility provided for in our campus CAS in Marine Biology Annamalai University at Parangipettai, India.

\section{References}

[1] Abraham K.C., Observations on the biology of Meretrix casta (Chemnitz). Zool. Soc. India, (1953) 5(2): 163-190.

[2] Jones S., The Molluscan fishery resources of India. Proc. Symp. Mollusc Marine Biology Association of India, (1970) 3: 906-918.

[3] Soares-Gomes A, Pires-Vanin A.M.S., Bivalve mollusk assemblages on São Paulo's Northern continental shelf, Southeast Brazil. Brazilian Journal of Biology, (2005) 65: 717-727.

[4] Suwat Tanyaros, Prasert Tongnunui., Influence of environmental variables on the abundance of estuarine clam Meretrix casta (Chemnitz, 1782) in Trang Province, Southern Thailand. Songklanakarin J. Sci. Technol., (2011) 33(1): 107-115.

[5] Baron J, Clavier J., Effects of environmental factors on the distribution of the edible bivalves Atactodea striata, Gafrarium tumidum and Anadara scapha on the coast of New Caledonia (SW Pacific). Aquatic Living Resources, (1992) 5: 107-114.

[6] Soares-Gomes A, Pires-Vanin A.M.S., Bivalve mollusk assemblages on São Paulo's Northern continental shelf, Southeast Brazil. Brazilian Journal of Biology, (2005) 65: 717-727.

[7] Mc Leod R.J, Wing S.R., Influence of an altered salinity regime on the population structure of two in faunal bivalve species. Estuarine Coastal and Shelf Science, (2008) 78: 529-540.

[8] Songrak A, Tongnunui P, Sawasdee A, Kongpom A., Population dynamics of hard clam (Meretrix casta Chemnitz, 1782) in the coastal area of Trang Province, Thailand. Proceeding on Conference of the International Journal of Arts \& Sciences, Salzburg, Austria, (2009) 1-4: 55-62.

[9] Narasimham K.A., Culture status of clam fisheries of India. J. Mar. Bioi. Ass. India, (1991) 33(1\&2): 76-88.

[10] Narasimham K.A, Laxmilatha P., CMFRI Bulletin-Artificial reefs and Sea farming technologies. Clam culture, (1996) 48: 76-87.

[11] Lee C., An ecological study on some marine bivalve beds of Korean tide lands. In: Proceedings of the Indo-Pacific Fisheries Council $13^{\text {th }}$ Sessions, Brisbane, Australia, (1972) 326-331.

[12] Fraga F, Vives F., Retention of particulate matter, in: Marine Mussels: Their Ecology and Physiology. B.L. Bayne Ed., Cambridge University Press, UK., (1960) 13-65.

[13] Jayawickrema E.M, Wijeyaratne M.J.S., Distribution and population dynamics of the edible bivalve species Meretrix casta (Chemnitz) in the Dutch canal of Sri Lanka. J. Aquatic Sci., (2009) 14: 29-44. 
[14] Tanyaros S, Tongnunui P., Influence of environmental variables on the abundance of estuarine clam Meretrix casta (Chemnitz, 1782) in Trang Province, Southern Thailand, Songklanakarin. J. Sci. Technol., (2011) 33(1): 107-115.

[15] Salih M.K.Y., On the growth of the backwater clam Meretrix casta (Chemnitz) in the clam beds off Cochin barmouth. J. Mar. Biol. Ass. India, (1973) 15(1): 345-353.

[16] Durve V.S, Dharmaraja S.J., On the probable change of form in the clam Meretirix casta (Chemnitz) during its growth. Proc. Sym. Mollusca Cochin. Mar. Biol. Ass. India, (1970) 2: 387-395.

[17] Sreenivasan P.V., Clam fishery resources of the Vellar estuary. Proceedings of Symposium on Post Harvest Technology of Fish, (1983) 57-62.

[18] Balasubramanian K, Natarajan R., Age and growth of Meretrix casta (Chemnitz) in Vellar estuary, Parangipettai. Bull. Cent. Mar. Fish. Res. Inst., (1987) 42(1): 145-147.

[19] Jayabal R, Kalyani M., Seasonal variation in biochemical constituents of the different body components of Meretrix meretrix (L.) Mahasagar. Bull. Natl. Inst. Oceanogr., (1986) 20 (1): 65-69.

[20] Seshappa G., Some observations on the backwater clam Meretrix casta (Chemnitz) in the Beypore and Korapuzha estuaries. Indian J. Fish., (1971) 14(1\&2): 298-305.

[21] Ramamohana-Rao V, Appa Rao T, Reuben S, Sampson A, Manickam P.E., On the culture possibilities of Meretrix casta in Bhimunipatnam backwaters. Indian J. Fish., (1977)24 (1, 2): 263-268.

[22] Jayawickrema E.M, Wijeyaratne M.J.S., Distribution and population dynamics of the edible bivalve species Meretrix casta (Chemnitz) in the Dutch canal of Sri Lanka. J. Aquatic Sci., (2009) 14: 29-44.

[23] Narasimham K, Muthiah A.P, Sundararajan D, Vaithinathan N., Biology of the great clam Meretrix meretrix in the Korampallam creek Tuticorin. Indian J. Fish., (1988) 35(4): 288-293.

[24] Tanyaros S, Tongnunui P., Influence of environmental variables on the abundance of estuarine clam Meretrix casta (Chemnitz, 1782) in Trang Province, Southern Thailand, Songklanakarin. J. Sci. Technol., (2011) 33(1): 107-115.

[25] Hornell J., The utilization of coral and shells for lime burning in the Madras Presidency. Madras Fish. Department Bull., (1916) 8: 105-126.

[26] Rai H.S., The shell fisheries of the Bombay Presidency. J. Bombay, Nat. Hist. Sac. (1932) 35(4): 884-847.

[27] Lakshmilatha P, Sujitha Thomas M.P, Sivadasan N.P, Ramachandran V.G, Surendranathan, The fishery and biology of Meretrix casta (Chemnitz) in the Moorad estuary, Kerala. Indian J. Fish., (2006) 53(1): 109-113.

[28] Galtsoff P.S, Chipman W.A, Engle J.B, Calderwood H.N., Fish. Bull. Fish. Wild Life Serv. U.S., (1947) 51-59.

[29] Koringa P, Postma H., Investigations into the fertility of the Gulf of Naples and adjacent salt lakes, with special reference to shellfish cultivation. Pubbl. Staz. Zool. Napoli, (1957) 24: 229284.

[30] Balasubrahmanian K, Natarajan R., Seasonal variations in the biochemical composition of Meretrix casta (Chemnitz) occurring in Vellar estuary. Cen Mar Fishe. Resea. Institute Bull. India, (1988) 42(1): 344-348.

[31] Thangavelu R, Poovannan P., Bivalve resources of Palar Estuary. Mar. Fish. Infor. Serv., (2007) 191: 1-5. 